\title{
SUSTAINABILITY OF DWELLINGS IN THE CONTEXT OF THEIR RESIDENTS' OPINION
}

\author{
Velta Parsova, Anita Sidelska \\ Latvia University of Agriculture \\ velta@parsova.lv, anitasidelska@inbox.lv
}

\begin{abstract}
The aim of the study was to analyse qualitative and quantitative indicators of the housing stock in Latvia and to compare them with the average indicators of the European Union and the Baltic States. The data of Eurostat on housing stock in the European Union, information of the Central Statistical Bureau on Population Census of Latvia were used. The survey was carried out to find out the households' opinion regarding their dwellings and housing evaluation criteria for selection of housing. The conclusions contain housing evaluation criteria for appropriate housing and recommendations for improvements of the housing policy.
\end{abstract}

Keywords: household, dwelling, characteristic of housing stock, criteria of dwellings, residential building.

\section{Introduction}

Housing is an important environment for many aspects of human life and healthy living; it is one of the main indicators of the national well-being. The households' requirements and opinions for appropriate housing differ depending on a given time period. Improvement of living standards and technological advancement enhance the people's need and desire for better housing. The residents of Latvia are willing to have similar dwellings to those of other European countries. The problem is that, on the one hand, the current housing stock not always satisfies the increasing requirements of households, but, on the other hand, the households' financial resources are too limited to buy another dwelling. However, there can be significant macro-economic gains for the country, if the government participates in the housing development.

One of the biggest problems in the second half of the previous century in Latvia was the lack of housing stock and its inappropriate management. Due to the migration processes within the Soviet Union there was a rapid increase of the population, therefore there was an acute shortage of dwellings in Latvia. In addition, residential housing has not been renovated for several decades. It happened often that funds for repairing and renovation were allocated only when a building was in the state of emergency or even dangerous for people. These factors affected the amount of the housing stock, its accessibility and quality. The repairing or demolition of improper residential buildings has become one of the most significant problems to their owners and local governments.

An important stage in the development of the housing stock in Latvia was the privatization according to which the tenants of flats in the residential buildings could obtain the flats in their property. It resulted in the decrease of the role of state institutions in maintenance and development of the housing stock, but the influence of free market conditions increased. Consequently, local governments lack housing stock to provide dwellings for low-income families. In Latvia there are no common requirements for minimum level of comfort, the number of rooms and other housing indicators. It is important for the long-term housing development strategy and territorial planning, construction development, real estate sales or lease market, infrastructure development. The selection of dwellings for living is based on people's desire, financial situation and real estate offer.

There is not much research done on the issue of dwellings and development of housing stock in Latvia. The prevention of housing crises and issues of dwelling policy have been researched by A. Bormane (2004) and J. Kučinskis (2006). S. Treija (2000) focused on future development of territories of Riga, V.Skribans and R. Počs (2007) investigated the necessity of dwellings and construction development, K.Vītola (2008) analysed the housing stock investment model in conditions of market economy applying a modelling method. There are more research publications on migration and periurbanization processes, geographic mobility of population by P. Eglīte et al. (1997), Z. Krišjāne et al. (2007), Z. Krišjāne, M. Bērziņš (2009).

\section{Materials and methods}

A dwelling includes a house, a flat or any other building or part of building suitable for living. Buildings or a group of rooms in the buildings, which have long-term roofed structures and entrances 
designated for giving a shelter to people, can be used by households for permanent living [1]. The total amount of residential units create housing stock, which characterizes availability of housing in the defined area. Housing stock and a dwelling are closely related concepts, which include general indicators (housing stock) and specific indicators of a household (dwelling). There are several definitions of household. In the framework of this research a household is considered to be a social unit of people linked by family ties or other personal relationships sharing every-day expenses and living in a shared common residence (a house, a flat). The factors determining the requirements for a dwelling include the number of rooms, its area, location, availability of public transport etc. $[2 ; 3]$.

The aim of the research is to find out the households' opinion regarding current dwellings and the ways of their improvement in Latvia. The qualitative research method (a survey) was used to find out the respondents' $(n=424)$ opinion. The research used the data of the Central Statistical Bureau (CSB) and 2011 Census Results of the Republic of Latvia; the comparison between Latvian dwellings and those in other European Union countries was based on the Eurostat data. Statistical analysis was carried out using descriptive statistics (graphs, charts, indicators); two-factor variance analysis, logical constructs and interpretation.

\section{Results and discussion}

Housing stock in Latvia accounts for 71 thousand $\mathrm{m}^{2}$ and it has not increased in the last three years due to reduction of construction capacity. In the EU an average area of housing stock in 2015 was $452 \mathrm{~m}^{2}$ per 1,000 residents. According to the Eurostat data the list of countries ranked by the average area of housing stock per 1,000 residents was the following: Spain $\left(544 \mathrm{~m}^{2}\right)$, Finland $\left(531 \mathrm{~m}^{2}\right)$ and Denmark $\left(500 \mathrm{~m}^{2}\right)$. The data show that among the Baltic States Estonia ranked first $\left(485 \mathrm{~m}^{2}\right)$ followed by Latvia $\left(462 \mathrm{~m}^{2}\right)$, which had the housing stock figures above the average area of the EU per 1,000 inhabitants. The least amount of area per 1,000 inhabitants was found in Slovakia $\left(326 \mathrm{~m}^{2}\right)$ and Poland $\left(345 \mathrm{~m}^{2}\right)$ [4].

The statistical data in Latvia showed that there were 402 dwellings per 1,000 inhabitants [5]. It means that each household had more than one dwelling. The average area of dwellings in 2012 in the EU was $95.9 \mathrm{~m}^{2}$, but the smallest figures of the average area were in Latvia $\left(62.5 \mathrm{~m}^{2}\right)$ and Lithuania $\left(63.2 \mathrm{~m}^{2}\right)$, which was twice as less than in Luxembourg $\left(131.1 \mathrm{~m}^{2}\right)$ and Cyprus $\left(141.4 \mathrm{~m}^{2}\right)$. According to the statistical data of the CSB, there was less than one room (0.94) per capita in Latvia which points to certain overpopulation. The area of a dwelling per capita in 2012 in Latvia was $35 \mathrm{~m}^{2}$, but as regards Western Europe and Nordic countries, the area per capita was approximately $40 \mathrm{~m}^{2}[6 ; 7]$. Historically the areas of flats were quite small, the average area of a dwelling in Latvia in 2015 was 64 $\mathrm{m}^{2}$ and it had increased by $2 \mathrm{~m}^{2}$ since 2007 [8].

The survey was carried out by the authors to find out the households' opinion regarding their dwellings. The total number of respondents was 424 . The questionnaire included questions about the present dwelling, its evaluation, the respondents' opinion regarding the factors that would influence the choice of dwellings and demographic information. It should be taken into account that housing stock is very varied in terms of the floor space, the level of amenities, the number of rooms, the most common type of housing etc. The results showed that more than $80 \%$ of the respondents were from cities and towns, out of which $37 \%$ respondents were from Riga and $24 \%$ were from municipality towns, but $19 \%$ of the respondents lived in the rural area. $86 \%$ of Riga residents lived in multi-storied buildings with ten and more flats [5]. Pieriga region experienced a rapid growth of newly built dwellings with larger floor space. The concentration of housing stock in the neighbourhood of Riga was related to an increasing number of work places and growing availability of different services [9].

Segregation and seclusion have become a characteristic feature of current society, which is expressed by the desire of wealthy people to live among people of similar incomes. This trend resulted in emergence of new residential areas around big cities. The areas have become living and sleeping areas, which provide dwellings according to individual wishes of owners, but do not offer either jobs or social services - educational, medical etc. institutions.

Dwellings could be divided into two groups - single-family houses and several-family houses. $62 \%$ respondents lived in residential buildings, $34 \%$ - in private houses, but an option of another type (an individual house in the countryside, a terraced house, a house owned by the local government, a 
hostel etc.) was chosen by $4 \%$ of the respondents. The results of the answers to this question were relevant to the total distribution of the types of dwellings in Latvia according to the Census 2011: $69 \%$ of dwellings were in the residential buildings, and $26 \%$ of the population lived in private houses (a single-family house or a single-family house in the countryside). The comparison with the distribution of the types of dwellings in the EU member states shows that Denmark (65\%) and the Netherlands $(58 \%)$ ranked first in the list of the number of private houses, but the Baltic States ranked first in the list of the number of residential buildings with $75 \%$ of households living in dwellings in residential buildings in Latvia, $68 \%$ of those in Lithuania and $63 \%$ in Estonia $[4 ; 10 ; 11 ; 13-15]$.

Investigating the ownership status of dwellings, the results showed that $52 \%$ of the respondents were owners of their dwellings, $12 \%$ had inherited them, and $5 \%$ had built their own house. According to the statistical data of the CSB, $59 \%$ of the dwellings belonged to a member of the household and $13 \%$ of the dwellings were rented [12]. The analysis of the ownership status of dwellings in the European Union gives evidence that $71 \%$ of individuals live in the dwelling they owned, but $41 \%$ of households live in flats and $34 \%$ live in private houses. In such countries as Denmark and the Netherlands, dwellings always have been a private property and ownership was transferred from one generation to the next. By contrast, in the Baltic States until the 90-ties of the previous century, only private single-family houses were privately owned whereas flats became the property of households in the process of privatisation of the housing stock $[13 ; 15]$. The authors of the article consider that the ownership rights is one of the factors that influence the satisfaction of households with the dwelling.

$40 \%$ of the respondents stated that they had lived in their only (the first) dwelling longer than 10 years, but $30 \%$ stated that they had lived from 2 to 5 years. Only $9 \%$ of the respondents had lived there less than two years. The survey results show that $18 \%$ of the respondents were completely satisfied with their dwelling, $65 \%$ were mostly satisfied, $17 \%$ were mostly dissatisfied or completely dissatisfied with their dwellings. It means that the existing housing stock more or less corresponds to the requirements of the households.

Table 1 contains ten housing evaluation criteria and the results of the survey, which shows the respondents' opinion when selecting a dwelling. The respondents chose one or several criteria, which households should take into account when selecting a dwelling.

Table 1

Households' opinion regarding the criteria of conditions of current housing (\%)

\begin{tabular}{|c|c|c|c|}
\hline \multirow{2}{*}{ Housing evaluation criteria } & \multicolumn{2}{|c|}{ Current dwelling } & \multirow{2}{*}{$\begin{array}{l}\text { Could consider in } \\
\text { the selection of } \\
\text { another dwelling }\end{array}$} \\
\hline & satisfied & dissatisfied & \\
\hline Housing maintenance expenses & 31 & 56 & 85 \\
\hline Road and public transport availability & 66 & 8 & 76 \\
\hline Amenities of housing and neighbourhood & 65 & 7 & 70 \\
\hline Energy efficiency of the housing & 12 & 42 & 66 \\
\hline Safety of housing and neighbourhood & 47 & 14 & 62 \\
\hline Accessibility of services & 46 & 11 & 57 \\
\hline Construction guaranty of a building & 7 & 31 & 50 \\
\hline Job opportunities & 21 & 16 & 49 \\
\hline Prestigious neighbourhood & 21 & 6 & 23 \\
\hline $\begin{array}{l}\text { Dwelling's influence on the environment and } \\
\text { community }\end{array}$ & 7 & 3 & 14 \\
\hline
\end{tabular}

Source: the survey $n=424$ and the authors' calculations

Two-factor variance analysis was used to process the obtained data and to find out the effect of the location of the housing and ownership status on satisfaction with the dwelling. With the probability of $95 \%$ there was statistically significant effect between the housing location (rural area or municipality town, Riga or a town) and such housing evaluation criteria as roads and public transport availability $(p$-value $=0.000)$ and accessibility of services $(p$-value $=0.047)$ i.e. $<0.05$. As regards energy efficiency of the housing and its location, they had an impact of a positive trend with the probability of $90 \%$ among other criteria since the $p$-value was 0.076 or it did not exceed 0.1 . The 
results show that households were satisfied with dwellings if roads and public transport and services were available. The most often mentioned negative opinion of the respondents concerned low energy efficiency of dwellings.

Housing maintenance expenses is an important quantitative indicator, which includes payment for housing and utility costs: payment for housing, i.e. the rent or monthly repayment for the loan; cost of water and sanitation, electricity, gas or other source of energy and heating.

The satisfaction with housing depends on the balance between the maintenance expenses and households' incomes. The analysis of the statistical data regarding housing maintenance expenses gives evidence that in 2015 households spent 138.2 EUR monthly on average or $16.4 \%$ from their incomes for maintenance expenses.

The residents of cities spent $17.3 \%$, which is slightly more, but the residents of rural areas spent $13.9 \%$ from their household incomes [8]. The authors consider that in case of similar housing maintenance expenses their absolute values vary depending on the location of the housing. In rural territories the housing maintenance expenses were lower, because available utility services were less on offer and they were cheaper. There was a possibility for households to choose the cheapest service, however, it was not always possible due to limited access in a certain area.

The results of the survey show that $85 \%$ of the respondents prefer housing maintenance expenses as the most important criterion, $76 \%$ of the respondents consider that the road and public transport availability are important, $70 \%$ of the respondents give priority to the amenities of housing and neighbourhood, which are followed by the criteria of conditions of energy efficiency of the dwelling $(66 \%)$ and by construction guaranty of buildings $(50 \%)$. The least amount of the respondents considered an influence of housing on the environment $(14 \%)$ and a prestigious neighbourhood (23\%) very important in the selection of another dwelling. The comparison of the data of different years starting from 2005 in Fig. 1 shows that the number of dissatisfied households has decreased from $53.6 \%$ in 2005 to $39.5 \%$ at the time of the survey.

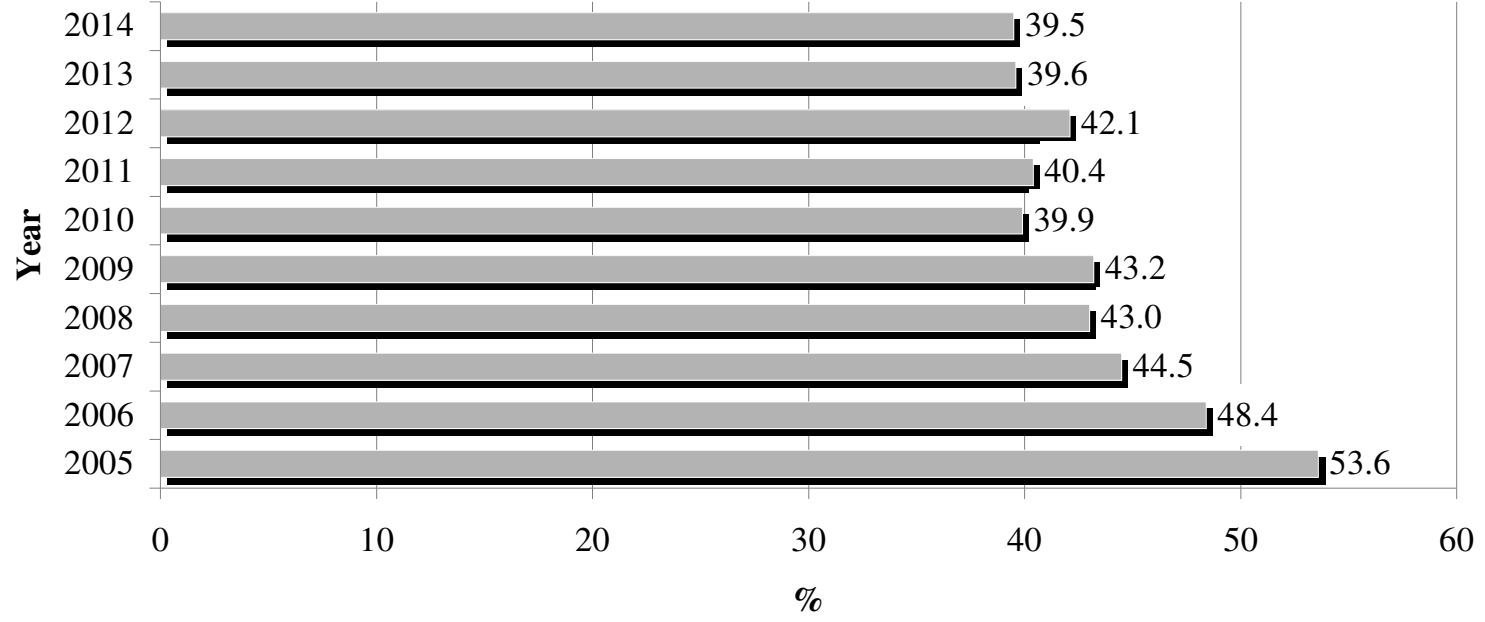

Fig.1. Share of households dissatisfied with their housing conditions.

The reduction of the number of households dissatisfied with the dwellings could be explained by the improvement of the housing conditions or the movement to another dwelling. The ownership status of dwellings had a statistically significant effect with $95 \%$ probability on all other housing evaluation criteria describing current satisfaction of the respondents regarding their housing except the criterion of housing influence on the environment and community $(p$-value $=0.509)$ and amenities of housing and neighbourhood $(p$-value $=0.068)$. Thus, households considered social, safety and economic issues important for choosing their housing. As regards the influence of the location and the ownership status of dwellings on satisfaction with the current housing, there was not a statistically significant effect only on households' satisfaction with housing influence on the environment and community $(p$-value $=0.224)$. Other criteria had a statistically significant effect with $95 \%$ probability on all other housing evaluation criteria describing current satisfaction, but the criteria of housing maintenance expenses, a prestigious neighbourhood and availability of roads and social infrastructure 
had the most significant effect ( $p$-value $=0.000$ ). The majority of the respondents were not satisfied with the housing maintenance expenses (56\%), energy efficiency (42\%) and construction guaranties $(31 \%)$.

The two-factor variance analysis was used to analyse the satisfaction of the households with the current dwelling, its location and ownership status. The results show that there is a statistically significant effect with $95 \%$ probability between the location of a dwelling and job opportunities $(p-$ value $=0.000)$, availability of roads and public transport $(p$-value $=0.001)$ and energy efficiency conditions $(p$-value $=0.040)$. The authors hold the view that the result could be explained by the reduction of vacancies in rural areas. The lack of roads and public transport restricted households from finding a job in the neighbourhood. The analysis shows that there is a statistically significant effect with $95 \%$ probability between the ownership status, and job opportunities $(p$-value $=0.002)$, construction guaranties $(p$-value $=0.010)$, service availability $(p$-value $=0.044)$. The authors conclude that ownership status and the location did not influence strongly the satisfaction with the housing and the reasons with the dissatisfaction in both cases were similar, since the analysis showed that there is a statistically significant effect with $95 \%$ probability between dissatisfaction with the current dwelling and job opportunities $(p$-value $=0.001)$, construction guaranties of a building $(p-$ value $=0.000$ ), availability of services $(p$-value $=0.026)$. The dissatisfaction with housing conditions described by the evaluation criteria influences the choice of a new dwelling. The respondents ranked housing maintenance expenses $(85 \%)$ as the most important indicator, followed by the availability of roads and public transport (76\%), amenities of housing and neighbourhood (70\%), conditions of energy efficiency $(66 \%)$ and construction guaranty $(50 \%)$. The least number of the respondents would take the criteria of the housing influence on the environment and community $(14 \%)$ and a prestigious neighbourhood $(23 \%)$ into account. The conclusion can be made that households will make economically grounded decision in choosing a new dwelling - maintenance expenses, roads and social infrastructure, amenities of neighbourhood and housing energy efficiency.

The survey results give evidence that households are willing to improve the condition of housing and environment around it. Thus $19 \%$ of the respondents were willing to improve the living conditions and $19 \%$ of the respondents wanted to reduce the housing maintenance expenses. Environmentally friendly power supply systems and sewage systems prevent environmental pollution. Another strategy of the housing policy in Latvia is insulation of buildings. $27 \%$ of buildings had been built at the beginning of the previous century, therefore the insulation capacity of $61 \%$ of residential buildings is very low and the heat consumption is very high and unfriendly to the environment. One of the options is the use of the EU funds for the improvement of housing insulation. The housing standards are influenced not only by the type, time of construction, materials, location of buildings, but by the overall living standards, socio-economic activity of a region, households' income and housing maintenance costs [15]. The survey results show that households are willing to improve the current housing level or obtain another dwelling to improve the living standards. The respondents were not satisfied with worn-out, abandoned and unfinished buildings.

\section{Conclusions}

1. Households were satisfied with dwellings if roads and public transport were accessible and services were available. The most often mentioned negative opinion of the respondents concerned low energy efficiency of dwellings.

2. Satisfaction with housing depends on the balance between the maintenance expenses and households' incomes. On average households spent about 140 EUR monthly or $16 \%$ from their incomes for maintenance expenses. $40 \%$ of all households had difficulties in paying the bills and only $14 \%$ admitted that they did not have any problems. Such proportion could become dangerous for an area if, in case of worsening of the economic situation (increase of the unemployment, bankruptcy of a company, reduction of production volumes or increase of the prices for gas, electricity, fuel etc.), people will not be able to cover the housing maintenance expenses.

3. The results of the survey show that $85 \%$ of the respondents prefer housing maintenance expenses as the most important criterion when selecting a new dwelling, $76 \%$ of the respondents consider that the road and public transport availability is important, $70 \%$ of the respondents give priority 
to the amenities of housing and neighbourhood, which are followed by the criterion of the conditions of energy efficiency of the dwelling (66\%).

\section{References}

1. Paršova V. Normatīvo aktu piemērošana nekustamā īpašuma formēšanā. 3.daļa: Dzīvokḷa īpašumi (Application of legislative acts in real estate formation. Part 3: Residential properties). 2008, Jelgava, LLU. 71 lpp. (In Latvian)

2. Kučinskis. J. Mājokḷu politika un tās instrumenti (Housing policy and its instruments), Rīga: Latvijas Hipotēku un zemes banka. 2006, 430 lpp. (In Latvian)

3. Sidelska A., Parsova V. Criteria of Dwelling Quality. In: C.Ellul, S.Zlatanova, M.Rumor \& R.Laurini (ed.), Urban and Regional Data Management UDMS Annual 2013, Taylor \& Francis Group, 2013, London, 13-22 pp.

4. Housing Statistics in the European Union 2010. Ministry of the Interior and Kingdom Relations. [online] [02.03.2015]. Available at:

https://www.bmwfw.gv.at/Wirtschaftspolitik/Wohnungspolitik/

Documents/housing_statistics_in_the_european_union_2010.pdf

5. Mājokḷli (Dwellings) Centrālā Statistikas pārvalde. 2012, [online] [28.01.2013]. Available at: http://data.csb.gov.lv/Dialog/Saveshow.asp. (In Latvian)

6. Bormane A. Mājokḷu problēmas risināšana mūsdienās dažādās Eiropas valstīs (Solving of housing problem nowadays in various European countries). Rīga, 2004, (In Latvian)

7. Eurostat. Living conditions in Europe. Eurostat Statistical books. Edition Luxembourg: Publications Office of the Europen Union. 2014, 134 p.

8. Iedzīvotāji un sociālie procesi (Population and Social Processes). LR Centrālā statistikas pārvalde. 2013 [online]. [25.07. 2014]. Available at: http://www.csb.gov.lv/statistikas-temas/iedzivotajidatubaze-30028.html (In Latvian)

9. Bērziṇš M., Krišjāne Z., Krūzmētra Ž. Peri-urbānās attīstības iezīmes Pierīgā (Features of periurban development in Riga surrounding). Zemes un vides zinātnes. LU. Latvijas Universitātes Raksti: 752.sēj., Rīga, 2010, 253.-267.lpp. (In Latvian)

10. Eurostat. Statistics Income, Social Inclusion and Living Condition [online] [19.05.2016]. Available at: http://ec.europa.eu/eurostat/web/products-statistical-books/-/KS-04-15-567

11. Metnieks I. Jaunie projekti. No eiforijas līdz panikai, no attīstības līdz stagnācijai (New projects. From euphoria to panic, from the development to stagnation). In: Nekustamais īpašums Latvijā 1991-2012. Latio. Nekustamie īpašumi. 2013, Rīga, 258.-294.lpp. (In Latvian)

12. Ienākumi un dzīves apstākḷi Latvijā 2012.gadā (Income and living conditions in Latvian in 2012) statistisko datu krājums. LR Centrālā statistikas pārvalde. 2013, 70 lpp. (In Latvian)

13. Sidelska A. Development of Housing Fund in the Regions of Latvia. Proceedings of the international scientific conference "Economic Science for Rural Development" Nr.26, LUA, Jelgava, 2011, pp. 207-213.

14. Human Development Report 2013 team. United Nations Development Programme. [online] [12.09. 2014]. Available at: http://hdr.undp.org/en/2013-report

15. Sidelska A. Characteristic of Housing Fund in European Countries. Proceedings of the international scientific conference of Agriculture Universities of Baltic States „Baltic Surveying'11". LLU, Jelgava, 2011, pp. 125-131. 